\title{
THE ROLE OF YOUNG PEOPLE IN RESISTANCE AGAINST THE SOVIET RULE AMONG THE NORTHERN PEOPLES IN THE 1930s-1940s
}

\author{
Art Leete
}

\begin{abstract}
At the beginning of the 1930s, the life of the northern peoples in Soviet Russia started to change rapidly. The new way of modernisation which predicted collectivisation, reorganisation of local administrative system, education, and religious life remained rather incomprehensible for the local communities. In many instances, the local groups of the northern peoples resisted these changes. In addition, a few attempts of armed resistance were undertaken. The article analyses some aspects of a prominent uprising which was organised by the Khanty and the Forest Nenets in West Siberia in the early 1930s. This uprising was known among the local indigenous population as Kazym War. The aim is to analyse the limited data that reflects the participation of women and young people in this uprising. As a rule, archival and literary sources do not concentrate on the fate of these groups in the Kazym uprising. However, since life in the northern tundra demands a tight integration of action by all age and gender groups, it may be supposed that men could not be engaged in longterm resistance activities without the support of their family members. While the role of young people seems to be mainly passive in the indigenous resistance of the early Soviet period, some Khanty writers have described in their novels the resistance experience of women and children. I aim to compare the reflections of the young people's role in the Kazym revolt in various sources.
\end{abstract}

Key words: children, the Khanty, the Nenets, resistance, young people

"The young generation of the whole Soviet

North declare in a "monolithic" spirit: Life

has become better, life has become more amusing."

(Voblov 1938: 30)

The large-scale radical social and political changes that the communities of the northern peoples of Soviet Russia were forced to go through during the early Soviet period put enormous challenges before these peoples. The northern peoples had to meet the demands of the new regime and they tried to survive in the situation of a rapid cultural change. Different groups and individuals made different choices in this situation. In most cases the adaptation took place in superficial collaboration and silent resistance. However, in a few cases, 
some northern peoples' communities resisted the Soviets by engaging also in armed protests. This paper is the analysis of the young people's participation in these tragic events.

Most uprisings of the northern peoples took place in Western Siberia (at least, there is more information about the most tragic events in this area). In the 1930s-1940s, the way of life of the Nenets, Khanty, and Mansi - the peoples who were living in the taiga and tundra belts of Western Siberia - underwent a considerable change. In 1933-1934, the struggle against the Soviet rule culminated in a revolt that has become known among the indigenous population as the Kazym War. It was a major attempt in the recent history of the Khanty and Nenets people to defend by force and arms their traditional rights against administratively enforced cultural changes. The Tundra Nenets on the Yamal Peninsula and the Bol'shezemel'skaia (Big Land) tundra in the European part of Russia organised three major uprisings, called mandaladas, in 1934 and 1943. On the Vakh River, the Tolka protest of the Khants took place at the beginning of the 1930s. Other parts of Siberia are represented only by a few major revolts. In 1932, the indigenous peoples of the Taimyr Peninsula (the Nenets, the Dolgans, the Evenki, and the Nganasans) carried out quite a prominent resistance event. The Chukchee organised the latest collective armed resistance in 1949. It has to be borne in mind that in order to analyse the problem of the participation of young people in these violent protests, one can rely only on the available data about the indigenous groups of Western Siberia. This area is, at least partly, covered in available sources.

It was mainly the adult male population who was involved in the northern peoples' resistance against the Soviets during the 1930-1940s. Their families were also involved in these events. When people gathered into camps or moved away from the Soviet administrative centres during these resistance activities, the families, in most cases, held together. Women and young people were thus already involved in the resistance activities.

One of the most prominent uprisings, the Kazym War, was provoked by the local authorities who established a boarding school in the village of Kazym and gathered children from taiga and tundra into the school. The parents of these children invaded the boarding school and took their children back to home camps. This means that at least in one case, children played a decisive role in the resistance activities.

In Soviet documents, the participation of children in protest actions and the destiny of the young indigenous people have not been indicated. The main sources that have been used in this paper are the works by Khanty writers which deal with these issues, some notes from the works of other scholars, and a few comments on this topic taken from interviews carried out among the Khanty. 
The most prominent novel on the events of the Kazym revolt (Mother of God in Blood-Red Snows) is by a Khanty writer Eremei Aipin (2006). The novel includes a number of descriptions of real events, and at the end of his book Aipin (2002: 285-302) has included a selection of archive documents connected with the Kazym revolt. The analysis of Aipin's descriptions is complicated because it is not an easy task to determine whether particular pieces of information are rooted in the authors' fantasy, local oral history, or documents. The destiny of the Khanty children in the Kazym revolt is also briefly addressed in a few short stories by Aipin (1995).

Another prominent work on this topic is a story written in 1987 by the Khanty scholar Tatiana Moldanova (In a Lonely Nest, alternative title The Middle World of Anna from Malanga). This work has had a significant impact on the perception of the Kazym uprising, much like Aipin's novel has now. And in both works, the Khanty children assume quite an important role.

\section{PASSIVE PARTICIPATION IN RESISTANCE ACTIVITIES}

In most cases the involvement of children in the Kazym revolt is described as passive. Women and children traditionally followed the male heads of families and thus they also appeared in the camps of protesters. After the resistance was suppressed, many adult males were arrested by the Soviets. Women and children stayed in the taiga and tundra, suffering from lack of food. Famine was especially severe for children, many of who died during the period following the uprising.

In the latest novel by Aipin, the Red commander Chukhnovski let the reindeer herd of a Khanty family to run off, destroyed nartas and reindeer sleighs, confiscated rifles, axes, and knives. As mentioned, a common practice of the Red Army soldiers was also destroying or confiscating food supplies, burning down chums (conical tents), arresting older boys and raping women. Even when some of these atrocities were not committed, families in the forest faced death, as most resources were taken away or destroyed (Aipin 2002: 23-25).

Aipin's descriptions are in accordance with reality. Similar behaviour of the Red Army troops in the Khanty winter camps is also recorded in the story by Tatiana Moldanova. Moldanova (1995: 85-86) has added reindeer skins and winter clothes to the list of confiscated items. Tolkachev (2000: 309-310), Ogryzko (1993: 9), Golovnev and Osherenko (1999: 94-95) describe similar confiscations which were carried out by the Red Army or secret police troops and the starvation of women and children after suppressing mandaladas, the uprisings of the Nenets of the Yamal Peninsula and Big Land tundra in 1943. At 
the same time, Aipin's descriptions are the most gruesome of the kind. While official documents contain only lists of items confiscated at the Khanty camps, no comments are made about the real confiscation process. The contemplation of the husband of the main character in Moldanova's story during his arrest and confiscation of belongings about the future of their children is quite typical:

My children will not survive. I had no time to teach my sons how to hunt game and fish. Although my wife is strong, she is merely a woman. And those [soldiers - A. L.] took the rifle away. No, they will not survive. (Moldanova 1995: 86)

Aipin also describes another practice of the Red Army troops - murdering entire chums of the Khants and the Nenets. In order to avoid accusations of killing innocent children, women and the elderly people, soldiers did not ascertain who were inside the chums. They simply opened fire on the chums and killed everybody inside. Afterwards the Reds announced that there could have been rebels inside and they could not take the risk of entering the chums and interrogating people (Aipin 2002: 165-169).

This kind of killing of indigenous people inside the chums is also described in connection with the suppressing of the Yamal Nenets mandalada in 1943. Viacheslav Ogryzko describes a meeting between the Nenets and operative staff members, relying on the story heard from a Nenets linguist Valentina Niarui:

In the year 1943, rumours were circulating in the Tambey tundra that there was a Nenets gathering in one of the camps, and that the Red agents could also come there. Reindeer herders were told to come without their family members, leave their wives at home, and not overload their nartas. On the designated day, all the Nenets who had come there were gathered to a chum. Suddenly, Chekists ${ }^{1}$ besieged the chum, an act of provocation was construed, and then they started shooting. Some of the Nenets tried to get out of the chum, escaping under the side edges rather than through the door, but they were also caught. Only a few of them were able to escape by jumping on the nartas and hiding themselves in the tundra. Among the extremely lucky who managed to escape was also Neleko, father of Valentina Niarui. He was only seventeen. When he tried to enter the chum, the narta-drivers ${ }^{2}$ blocked his entrance, fearing that it may be a trap set for local reindeer herders. They tied him to the narta and told him not to raise his head by any means, and to untie himself after the Red agents have left. When he had untied himself after the bloody battle, Neleko dared to look into the 
chum to search his father. He saw his father lying dead on his back, holding a tobacco box made of mammoth bone tightly in his hand.

The elderly Nenets say that another incident took place in the Kharsavey tundra. The hill with the remains of a blood-stained chum is still there. This is where the chum collapsed, decomposed and then there was just the hill. After the incident, in fear of death, the representatives of the northern peoples were not allowed to go near the shooting areas or bury the dead. (Ogryzko 1993: 9)

During my fieldwork, the Khants also told me that after the Kazym revolt, such things really did happen. Aipin (2002: 169) argues that the Reds even made written accounts of these killings.

One of the main motifs in the Aipin's novel is the destiny of a Khanty family. In this novel, a Khanty woman lost, one by one, almost all her family members (husband and children) and felt some kind of pull from the side of the World of Dead. But she suppressed her desire to die until she could save at least one of her kids (Aipin 2002: 170, 247-250).

The link between the destiny of children and a Khanty worldview becomes the strongest in a scene towards the end of Aipin's book. Aipin describes how the Mother of Children who had lost her husband (who was killed by the Red soldiers) and almost all her children (three of them were killed in bombing), reindeer and narta, crawled along narta tracks in the snow towards a Khanty camp. She was exhausted, but tried to drag her youngest child Savva along by a reindeer skin. Savva demanded food. The Mother of Children could not stand up and there was no food. Then she closed her eyes and had a vision about a mythical bird Kars, who was taking the Man of the Tale to some faraway place. The journey was long and the man ran out of meat. But Kars demanded more food. The Man of the Tale cut calves off his legs and fed those to Kars. When the journey ended, Kars asked him why the last two pieces of meat had a different flavour. The Man of the Tale told him that these were his calves that he had cut off. Kars vomited the calves out and reattached the man's legs. The Mother of Children was thus given a hint in her vision, so she took a knife, cut open her breast and fed her child her running blood. The mother's blood was to be the only food for Savva until they eventually reached the Khanty camp (Aipin 2002: 216-217; 2006).

Next to writers, the topic of children in the resistance has been touched upon by the Khanty and Nenets, who have shared their knowledge about the uprisings with researchers. Golovnev (1995: 187-189) has made some observations on this issue. In addition, one informant told me about his mother's situation after the Kazym uprising: 
My grandfather also suffered from [Soviet] repressions. My mother is now living in the Yuilsk village, she has got a paper. She was six years old at that time. She has a paper. [It is written there] that this, this and this person did not participate in the armed uprising. She got this kind of a paper. (Male, age 38, EA 240, Leete 1996: 57)

Issuing such documents to children was quite an absurd practice, but perhaps these were useful for the people when they became adult. They could avoid problems later in their lives by having such documented proof of their innocence.

One of the main episodes of the Kazym revolt was directly connected with the situation of children, who had a catalytic role in the following important events. In the autumn of 1931, Khanty children were forcibly taken to the boarding school of the Kazym Kult'baza (culture base) ${ }^{3}$. Hunting equipment was confiscated from and other administrative penalties were inflicted on the families who refused to give away their children. The 'agitbrigades'4 of the culture base took away 50 children to the boarding school that autumn (GAHMAO, Astrakhanceva 1934: 1. 5-6; Lukina 1993: 62; Kolga et al. 1993: 114; Barkalaya 1999b: 72; Taagepera 1999: 359-360). This fact is important in the memories of several Khanty and Mansi who have spoken about this event:

At first there was the conflict regarding the children. Children were taken away from school. The Khanty arrived there; all the kids were ill. They did not have their traditional food. They fed cabbages, potatoes and some sort of "worms" to the children. People were really thinking that the noodles were some kind of worms. [The Khanty thought that the Russians] fed worms to our children. The Khanty took their children away from school. [The Russians] arrived to agitate, again. It was not really an agitation! They [the Russians] forced the children back to school. They all [the Khanty] took their children and moved further away, to the Num-to region. The Khanty of the Yuilsk region joined them and everybody left for Num-to (Male, age 39, Khanty; EA 240, Leete 1996: 56-57).

It all started because the children were taken to school at that time. They [the Khanty] started to protest. It was told on the radio, also. ${ }^{5}$ They [the Khanty] made some kind of a petition or appeal. They did not just [protest], they gave an ultimatum or had a demand. The authorities, the Soviets, refused to meet their demands. [...] In general, it was about children. Perhaps [the Khanty] wanted their children to study in their camps, so that their children would not be Russified, so that they 
could make their own choices in life. But their request was denied. (Male, age 44, Khanty; EA 236, Leete 1995: 104-105)

The children were taken away to study at boarding schools. But who would want to give away one's child? (Female, age 75, Mansi; EA 234, Leete 1991: 83)

On 28 December 1931, the Khanty (50 men) arrived from the neighbouring Khullor village to the Kazym boarding school and took the majority of children home, to the forest and tundra. (GAHMAO - Astrakhanceva 1934: 16; GMPiCh - Loskutov 8, 1. 2; Loskutov 7, 1. 7; Kopylev \& Retunski 1965: 168; Budarin 1968: 215; Radchenko \& Smirnova 1994: 206, 226; Golovnev 1995: 169; Balzer 1999: 111; Ogryzko 2002; EA 234: 84)

In the memoirs of Arkadi Loskutov, the then director of the Kazym boarding school, the children were taken away in a rush. Each Khanty man took one child and on the way back to the forest the children were reunited with their parents. Loskutov denied the rumours that during the study period, the Khanty parents were not allowed to visit their children at the boarding school because of an epidemic ${ }^{6}$ and argued that ten parents (mothers) were constantly living in the boarding school together with their children. Loskutov also argues that these mothers had meals together with the children and mended their clothes. As expected, Loskutov blamed the kula $k \mathrm{~s}^{7}$ and shamans in all the problems surrounding the school, claiming that their agitation was motivated by their aim of sharpening the class struggle. According to Loskutov, the real problem was that the importance of kulaks and shamans in indigenous communities began to decrease and the Kazym culture base took over the leading role in several spheres (e.g., in political and economic spheres). Politically, the influence of the wealthy Khanty was challenged by the Soviet local authority, and economically by the integral cooperative enterprises which had obtained the lands expropriated from kulaks (GMPiCh, Loskutov 1, 1. 9-13).

After the Kazym uprising, many indigenous people fled from their seasonal camps to remote forest and tundra areas. The Soviets sent messages to tundra, promising that everybody could return to their camps and that there would be no punishment. Some families who did not participate directly in the uprising believed the promise and arrived at their winter camps. Contrary to what they expected, the male heads of these families were arrested and their hunting equipment (mainly rifles), winter clothes (and hides prepared for making these clothes), as well as food supplies were expropriated. The Soviet authorities justified the leaving of women and children without food and rifles in the tundra by a rumour that a Khanty woman had attacked the Red soldiers with a gun $^{8}$ (Moldanova 1993: 65-67; Ogryzko 2002). Many families faced famine in 
the seasonal camps and any children died through malnutrition or were killed by wolves (Moldanova 1993: 71-90; Aipin 1995: 144; Ogryzko 1998: 459). Estonian scholar Rein Taagepera (1999: 360) has estimated that several hundred people starved to death in these winter camps but the figure sounds rather unrealistic.

\section{ACTIVE PARTICIPATION IN RESISTANCE ACTIVITIES}

The role of women and young people was not only passive during these resistance events. Even the Soviet authorities agreed that in many cases women, young people, and even children fought against Red Army units consisting mainly of men (Golovnev 1995). Also, they were as desperate in their resistance as the male representatives of indigenous groups (Aipin 2002: 63). This provoked special attention on the Soviet side, so that in some cases also young people were killed during the oppression activities.

One event that has been described in connection with the role of children in the resistance was the shooting of a Soviet plane. For the first time I heard about the practice of the Red troops using aeroplanes against the indigenous people in fieldwork interviews:

And Chudnovski shot at chums from his plane. Yengukh shot that plane down. There was a big lake. The plane fell into the lake. But he, Chudnovski, ${ }^{9}$ survived. (Male, age 39, Khanty; EA 240, Leete 1996: 58)

The description of shooting down the plane can be also found in the Aipin's book. However, according to Aipin, the shooter was not Yengukh, a Nenets (or the anonymous character from the beginning of the novel who bears certain semblance to him), but a Khanty woman (Mother of Children) (Aipin 2002: 172-182).

In the novel the shooting of the plane was provoked by the bombing of a Khanty family (Mother of Children and her four children) in an empty snow field. The bombs killed three older children, a dog and the family's two last reindeer in two attacks. In extreme desperation, Mother of Children shot the plane down after her son Roman's attempt to hit the plane failed and he was fatally wounded (Aipin 2002: 64-73, 171-188, 194).

Aipin explains the bombing of the indigenous people who tried to escape from the area of the Kazym uprising with the belief that this was a predetermined plan of the Soviet authorities. The plan had two aims: first, to isolate the Khanty of the Kazym River and to prevent the diffusion of the uprising 
and, second, to make the survival more difficult for the Kazym Khanty and to completely break them both physically and mentally (Aipin 2002: 171-172).

Limited Soviet literature about the Kazym revolt, of course, does not confirm the information about the shooting of the plane by the Khanty. The local elders told the Estonian scholar Heno Sarv, who conducted fieldwork among the Kazym River Khanty in 1975, that the Khanty did not shoot the plane because they believed it to be some kind of god (from personal communication).

\section{DISCUSSION}

As a rule, the Soviet documents in which the events of the resistance of the northern peoples in the 1930s-1940s are described give no substantial information about the issue. It may be that the possible participation of children and young people in these events was not a very important problem for the Soviet authorities. At the same time, the pain inflicted by Red Army troops to (mostly) defenceless, innocent children and women was also an uncomfortable topic, and thus to be avoided, and the events were, perhaps, simply not mentioned in official records. The children who died of starvation in the taiga and the tundra after their fathers were arrested were not officially counted as casualties of the uprising. These facts were, then, of little consequence for the Soviet officials. The only event during the Kazym revolt which was directly connected with indigenous children was the attack against the Kazym culture base (Kultbaza) in December 1931. Similarly, in this case children were described just as victims of "the kulaks' and shamans' agitation".

The destiny of indigenous children has become quite an important issue for writers (Aipin, Moldanova) who have used the children's suffering after uprising as a key element in their stories. It is quite difficult to estimate the concentration of "objective truth" in these works (even though these texts are based on real events, and official documents and the oral history of the Khanty have been occasionally used by these authors). The emphasis on the situation of children in the works of indigenous authors definitely indicates that this issue is of great significance for the Khanty themselves.

This becomes even more evident if we consider that the younger generation of the Khanty of the 1930s-1940s carried the memories and oral lore about these events into the 1990s, when it became possible to talk about the resistance in the early Soviet period. The resistance still plays an important role in the identity of the northern peoples. 
The oral history of the Khanty and the Forest Nenets is a central source of information about the resistance events (because official documents fail to describe all the aspects of these events and do not include the viewpoint of the indigenous people). However, these oral history reports are quite difficult to interpret. People mix real events (some parts of which have sometimes been forgotten while different events have merged) and (mythical) heroic narratives. It should also be taken into consideration that indigenous people do not want to tell us everything they know about the events or how they feel about these.

An interesting angle in the Khanty narratives is the topic of shooting at the Soviet plane. In oral tradition this has been described as the act which was committed by adults. However, Aipin attributes the role of a shooter to a little boy. His description may be interpreted as the construction of an indigenous ideological image of a heroic boy who fought the enemies on the "right" side. This theme may be influenced by the Soviet heroic narratives about young boys attacking German tanks during the Second World War. ${ }^{10}$

Another possible parallel to this description is mythological. Heroic epic and even the folk tales of the northern peoples include descriptions of young boys fighting against monsters or giants. For example, narratives about Kaassassuk who was an orphan and teased and punished by others have been recorded among Greenland Inuit. Kaassassuk later grew stronger and revenged everybody who had insulted him (Eskimosskie 1988: 432-439). ${ }^{11}$ References to similar folk narratives can be found in Aipin's novel. ${ }^{12}$

An important aspect of the scene about shooting the plane by a boy is also that in this situation indigenous children cannot be regarded as simply the passive, innocent victims of Soviet repressions. ${ }^{13}$ In some cases the children also assumed an active role in the resistance, even though evidence of this happening can be found mainly in a fictional story by Eremei Aipin. Evidently, Aipin wishes to stress the possibility of total resistance which involved also women and children.

It may be agreed that the role of children and young people during the indigenous resistance in the North in the early Soviet period (in the 1930s1940s) was mainly passive, that of victims. In addition, the children have a covert role in these tragic events, as they later turned into a generation that transmitted to today's world the knowledge and memories about their fathers' and grandfathers' heroic attempts to resist the Soviet reforms. At the official level they were the first generation of indigenous peoples in the Russian North to enjoy a new, "better", and "more amusing" life. 


\section{ACKNOWLEDGEMENTS}

This research was supported by the EUROCORES BOREAS programme's project No. 007, the Estonian Science Foundation grant No. 6688 and the European Union through the European Regional Development Fund.

\section{NOTES}

${ }^{1}$ Chekists were members of Cheka (Chrezvychainaia Komissiia), the first Soviet state security organisation, created in 1917 by Vladimir I. Lenin. (Editor's note)

${ }^{2}$ I.e. the locals who had taken the Red agents there. (Author's note.)

${ }^{3}$ The Soviet central institution for organising reforms among the northern peoples, the Committee of the North, decided in 1925 to establish culture bases as the most prominent centres for civilising the peoples of the North. For this purpose, several facilities of infrastructure were built in the culture bases, such as houses of culture, hospitals, boarding schools, stores, at least for the local Soviets. The leaders of the Committee of the North liked the idea about sedentary indigenous people who have direct access to shops, schools, hospitals, and communication centres. Cultural bases were planned to be developed into exemplary settlements in remote regions far from old administrative and trade centres. Culture bases were a large-scale, radical form of social experiment that was supposed to introduce modernising culture changes. At the same time, culture bases were meant to be tools for collecting information about the indigenous groups of the North. (Gurvich 1987: 20; Forsyth 1989: 80; Balzer 1999: 107)

4 'Agitbrigades' were groups of active Soviet workers who were supposed to carry out Soviet propaganda. In this particular case the term 'agitbrigade' has been regularly used in Soviet archival sources and literature. Actually, propaganda was not the main field of action for these groups. These were just groups which aimed to influence the local indigenous groups to get their support to Soviet reforms.

5 A Khanty man explained the sources of his knowledge about the Kazym War as follows, "I do not even know exactly, I just know from conversations. The elderly mainly talk about this. Once I heard about it on the radio; there it was exactly told." (M 44, EA 236, Leete 1995: 103) It is likely that the Khanty man had listened to a programme on Yugoria, the radio station of the Khanty-Mansiysk Autonomous Okrug, where according to Tatiana Moldanova the events of the Kazym War took place. The information provided by the Khanty informant was in remarkable accordance with information available in literature.

6 According to Kopylev and Retunski (1965: 168), chicken pox spread among the children in the boarding school and the quarantine lasted for two weeks. During that time parents were not allowed to visit their children.

7 Kulak - (Russian: 'fist') the term that was used in the Soviet Union to designate a certain group of "enemies of the state". This group included, principally, a wealthy part of peasantry but in reality the term was applied in a much wider sense. 
8 Clearly, Aipin alludes to the wife of Grigori Sengepov, a Khant who was killed in a conflict between a group of Red Army soldiers and a local family. Aipin writes in his short story entitled "The Russian Doctor" that during the Kazym War, some Khanty women shot the Russians (Aipin 1995: 144). This information is not confirmed in other sources, although Golovnev (1995) and Moldanova (1995) allow that such rumours circulated.

${ }^{9}$ According to documents, it was, in fact, another Red officer, Bulatov, who participated in the bombing of the Khanty from the plane.

${ }^{10}$ This interpretation was suggested by Piers Vitebsky during the conference "Generation P in Tundra", which was held in the October 2004 in Tartu, Estonia.

${ }^{11}$ Motifs of small heroes successfully fighting giants and dragons are known worldwide in folktales and myths (see ATU 300, "The Dragon-Slayer", Uther 2004).

12 This remark was suggested by Piers Vitebsky.

13 This remark was suggested by Piers Vitebsky.

\section{ARCHIVE SOURCES}

EA $=$ Ethnographic Archives of the Estonian National Museum.

234, Leete 1991 = Leete, Art. Teateid mansidest [Reports of the Mansi], pp. 56104.

236, Leete 1995 = Etnograafilisi kirjeldusi Tjumeni oblasti Handi-Mansi AR Surguti rajooni Ai-Pimi jõe hantide kohta 1995. aasta augustist. Koostanud Art Leete [Ethnographic descriptions of the Khanty of the Ai-Pim River in Surgut District, Khanty-Mansiysk Autonomous Okrug, Tiumen Oblast. Compiled by Art Leete.], pp. 83-148.

240, Leete 1996 = Leete, Art. Etnograafiline materjal 1996. a. aprillis Vene Föderatsioonis Tjumeni oblastis Handi-Mansi autonoomses ringkonnas HantõMansiiski linnas ning Belojarski rajoonis toimunud ekspeditsioonist [Ethnographic fieldwork material collected from the Beloyarsk District and KhantyMansiysk in the Khanty-Mansiysk Autonomous Okrug, Tiumen Oblast, Russian Federation.], pp. 11-101.

GAHMAO = The State Archives of the Khanty-Mansiysk Autonomous Okrug, Yugra (Gosudarstvennyi arkhiv Khanty-Mansiyskogo avtonomnogo okruga):

Astrakhantseva 1934 = Vospominaniia L. N. Astrakhantsevy [Account by L. N. Astrakhantseva.] (material unindexed in 1991).

GMPiCh $=$ Scientific Archives of the State Museum of Natural History and Man of the Khanty-Mansiysk Autonomous Okrug, Yugra (Gosudarstvennyi Muzei Prirody i Cheloveka).

Loskutov = manuscripts of A. N. Loskutov, Inv. No. 2352/537:

1. O vosstanii kulakov $i$ shamanov na Kazyme $v$ 1933-34 gg. [About the Uprising of the Kulaks and Shamans on the Kazym River in 1933-1934.] 
7. Iz kulatsko-shamanskogo vosstaniia na Kazyme. [From the Uprising of the Kulaks and Shamans on Kazym River.]

8. $K$ istorii. [About the history.]

\section{REFERENCES}

Aipin, Eremei 1995. Kliatvoprestupnik. Izbrannoe. [A Breaker of the Word of Honour. Selected Stories.] Moskva: Nash sovremennik.

Aipin, Eremei 2002. Bozh'ia Mater'v krovavykh snegakh. Ekaterinburg: Izdatel'skii dom Pakrus.

Aipin, Eremei 2006. Mother of God in Blood-Red Snows. Ekaterinburg: Publishing House Pakrus. Partly available online at http://www.deputatandreev.ru/content/ data/attach/437/kniga_aipin_english.doc, last accessed in January 2009.

Balzer, Marjorie M. 1999. The Tenacity of Ethnicity. A Siberian Saga in Global Perspective. Princeton, New Jersey: Princeton University Press.

Barkalaya, Anzori 1999. Ortodoksisuus, taisteleva ateismi ja hantien kansanusko. [Orthodoxy, Belligerent Atheism and Khanty Folk Religion.] In: T. Laitila, T. Saarinen (eds.) Uskonto ja identiteetti. Suomalais-ugrilaisten kokemuksia ja vaiheita Venäjällä ja Neuvostoliitosta. [Religion and Identity: The Experiences of FinnoUgrians in Russia and the Soviet Union.] Helsinki: Suomalaisen Kirjallisuuden Seura, pp. 67-81.

Budarin, Mikhail A. 1968. Byli o Sibirskikh chekistakh. [Legends about the Siberian Chekists.] Omsk: Zapadno-Sibirskoe knizhnoe izd-tvo, Omskoe otdelenie.

Eskimosskie $1988=$ Eskimosskie skazki i mify. [Fairy Tales and Myths of the Eskimos.] Ed. by G. A. Menovshchikov. Moskva: Izd-tvo Nauka, Glavnaia redaktsiia vostochnoi literatury.

Forsyth, James 1989. The Indigenous Peoples of Siberia in the Twentieth Century. In: Alan Wood \& R. A. French (eds.) The Development of Siberia: People and Resources. London: Macmillan Press Ltd, pp. 72-95.

Golovnev, Andrei V. 1995. Govoriashchie kul'tury. Traditsii samodiitsev i ugrov. [Talking Cultures: Samoyed and Ugrian Traditions.] Ekaterinburg: Ural Branch, Russian Academy of Sciences.

Golovnev, Andrei V. \& Osherenko, Gail 1999. Siberian Survival. The Nenets and Their Story. Ithaca and London: Cornell University Press.

Gurvich, I. S. 1987. K socializmu, minuia kapitalizm. [Towards Socialism Skipping Capitalism.] In: I. S. Gurvich (ed.) Etnicheskoie razvitie narodnostei Severa $v$ soveckii period. [Ethnic Development of the Small Peoples of the North during the Soviet Period] Moskva: Nauka, pp. 11-31.

Kolga et al. 1992 = Kolga, Margus; Tõnurist, Igor; Vaba, Lembit \& Viikberg, Jüri 1993. Vene impeeriumi rahvaste punane raamat. [The Red Book of the Nations of the Russian Empire.] Tallinn: Nyman \& Nyman LNT.

Kopylev, Dmitri I. \& Retunskii, Vladimir F. 1965. Ocherki istorii partiinoi organizacii Tiumenskoi oblasti. [Essays about the History of the Party Organisation of Tiumen Oblast.] Sverdlovsk: Sredne-Ural'skoe knizhnoe izdatel'stvo. 
Lukina N. V. 1993. ***. In: E.V. Osokin (ed.) Severnaia kniga. [The Northern Book.] Tomsk: Tomskii regionalnyi otdel po sotsialno-ekon. razvitiiu raionov Severa, p. 62.

Moldanova, Tatiana A. 1995. V gnezdyshke odinokom. [In a Lonely Nest.] Na semi kholmakh sotsvetie. Al'manakh poetov i prozaikov Khanty-Mansiiska. Moskva: Uniserv, pp. 83-104.

Ogryzko, Viacheslav V. 1993. Neizvestnyi Sever. [The Unknown North.] Slovo Narodov Severa, No. 1, pp. 8-9.

Ogryzko, Viacheslav V. 2002. Ot sud'by ne ubezhish'. [You Can Not Escape Fate.] Literaturnaia Rossiia online. 29 March 2002. Available online at http://www.litrossia.ru/ archive/84/criticism/1965.php, last accessed on 30 July 2005.

Radchenko, N. D. \& Smirnova, M. A. (eds.) 1994. Sud'by narodov Ob'-Irtyshkogo Severa. (Iz istorii natsional'no-gosudarstvennogo stroitel'stva. 1822-1941 gg.) [Destinies of the Peoples of the North of the Ob-Irtysh Region. (From a History of National and State Construction. 1822-1941.] Sbornik dokumentov. Tiumen': Upravlenie po delam arkhivov Tiumenskoi oblasti, gosudarstvennyi arkhiv Tiumenskoi oblasti, Tiumenskii oblastnoi tsentr dokumentatsii noveishei istorii.

Taagepera, Rein 1999. The Finno-Ugric Republics and the Russian State. London: Hurst \& Company; New York: Routledge.

Tolkachev, Viktor F. (ed.) 2000. Rossiia. Krainii Sever. Vlast'. [Russia. Far North. Power.] Nenetskii krai: Skvoz' v'iugi let. Ocherki. Stat'i. Dokumenty. Arkhangel'sk: Pomorskii gosudarstvennyi universitet imeni M.V. Lomonosova, pp. 260-316.

Uther, Hans-Jörg 2004. The Types of International Folktales. A Classification and Bibliography. Based on the System of Antti Aarne and Stith Thompson. FF Communications Vol. CXXXIII. No. 286. Helsinki: Suomalainen Tiedeakatemia.

Voblov, Ivan 1938. Komsomol Chukotki. [The Komsomol of Chukotka.] Sovetskaia Arktika, 10-11 oktiabr'-noiabr', pp. 27-30. 